\title{
Confirmation of glyphosate resistance in two species of ryegrass from New Zealand vineyards
}

\author{
H. Ghanizadeh ${ }^{1}$, K.C. Harrington ${ }^{1}$, T.K. James ${ }^{2}$ and D.J. Woolley ${ }^{1}$ \\ ${ }^{1}$ Institute of Agriculture and Environment, Massey University, PB 11-222, Palmerston \\ North 4442, New Zealand \\ ${ }^{2}$ AgResearch, Ruakura Research Centre, PB 3123, Hamilton 3240, New Zealand \\ Corresponding author:K.Harrington@massey.ac.nz
}

\begin{abstract}
Plants were obtained from two populations of Italian ryegrass (Lolium multiflorum) and three populations of perennial ryegrass (Lolium perenne) from different vineyards in Marlborough and Nelson that were suspected of being resistant to glyphosate following many consecutive applications of this herbicide over recent years. Each population was multiplied by splitting out tillers, and this was also done for plants taken from a population of each species from Manawatu pastures where they had not been exposed to glyphosate application. A dose-response experiment showed that four populations taken from the vineyards were about 10 times as resistant to glyphosate as those plants that had not been previously exposed to the herbicide. The experiment was repeated and showed one perennial ryegrass population to have a 30 -fold level of resistance. These are the first confirmed cases of glyphosate resistance within New Zealand.
\end{abstract}

Keywords glyphosate, herbicide resistance, Italian ryegrass, Lolium multiflorum, perennial ryegrass, Lolium perenne, vineyard.

\section{INTRODUCTION}

Glyphosate is a non-selective, post-emergence herbicide with no soil residual activity that is suitable for controlling weeds in a wide range of situations including within vineyards (Franz et al. 1997). Glyphosate inhibits the enzyme 5-enolpyruvoylshikimate-3-phosphate synthase (EPSPS) within the shikimate pathway and so prevents production of the aromatic amino acids tyrosine, phenylalanine and tryptophan (Nandula 2010).

Although it was once thought that resistance to glyphosate was unlikely to evolve (Bradshaw et al. 1997), continuous applications of glyphosate have resulted in glyphosate-resistant weeds appearing in a range of situations overseas. Since the first case of glyphosate resistance was discovered in Lolium rigidum from Australia in 1996 (Powles et al. 1998), the number of species of glyphosate resistant weeds has increased and to date 24 weed species have been reported as having evolved resistance to glyphosate globally (Heap 2013).

The level of herbicide resistance is often expressed as a ratio of the dose required to reduce shoot weight by $50 \%$ relative to untreated plants $\left(\mathrm{GR}_{50}\right)$ of resistant and susceptible biotypes, abbreviated as the $\mathrm{R} / \mathrm{S}$ ratio (Beckie at al. 2000). The R/S ratio of weed species that become resistant to glyphosate is commonly between 2 and 15 (Preston et al. 2009), although some resistant biotypes have been reported as 
being over 100 times more resistant (Simarmata et al 2005).

Several mechanisms of resistance have been discovered for glyphosate, which can influence the level of resistance. Target-site resistance involving alteration of the binding site within the plant for the glyphosate molecule can give 2 to $15-$ fold resistance (Preston et al. 2009). A non-target site mechanism causing reduced translocation of glyphosate can give similar or higher levels of resistance (Wakelin \& Preston 2006).

In 2012, it was reported that glyphosate, used at the recommended rate, had failed to control an Italian ryegrass (Lolium multiflorum) population in a vineyard in Marlborough. Shortly after that, glyphosate was reported again to fail to control this species or perennial ryegrass (Lolium perenne) in four other vineyards in Marlborough or Nelson. Although these two species are commonly grown as pasture species within New Zealand, they can also be troublesome weeds in vineyards. Glyphosate is the cheapest and most effective herbicide for controlling these and most other weed species within vineyards, so this has been applied continuously for years in many vineyards (Dastghieb \& Frampton 2000; Harrington 2012).

No weed species has been confirmed as having developed resistance to glyphosate within New Zealand to date. The objective of this work was to determine whether resistance to glyphosate has evolved within these vineyards, and also to determine the magnitude of resistance if it was confirmed to exist.

\section{MATERIALS AND METHODS}

\section{First experiment}

Live plants from each of the five populations suspected of being resistant were obtained in November 2012. All were obtained from vineyards that had been sprayed with glyphosate for at least 10 years, usually two to three times annually, and now were no longer controlled by recommended rates of glyphosate. Plants of perennial ryegrass (cv. Trojan) and Italian ryegrass (cv. Tabu) were also obtained from paddocks at Massey University in Manawatu for comparison as they were from grazed swards unlikely to have been sprayed with glyphosate.
All plants were split into plantlets consisting of two to three tillers and each was established in separate polythene planter bags $(700 \mathrm{ml})$ filled with potting mix, a similar technique to that used by Wakelin \& Preston (2006) to multiply up ryegrass plants. The plants were then left in an unheated shade-house at Massey University to establish with automated overhead irrigation.

When new leaves had emerged and plants were judged to be sufficiently robust to be sprayed (average of 4.7 tillers per plant), different rates of glyphosate (isopropylamine salt as Roundup 360 Pro) were applied using a laboratory track sprayer calibrated to deliver 230 litres/ha at $200 \mathrm{kPa}$. Populations thought to be resistant were treated with $0,180,360,720,1440$ and $2880 \mathrm{~g}$ ae (acid equivalent)/ha and those thought to be susceptible received $0,22.5,45,90,180$ and $360 \mathrm{~g}$ ae/ha. Plants were allocated to treatments within a randomised block design with ten replicates, and blocking was done based on plant vigour. All herbicide treatments contained $0.1 \%$ organosilicone surfactant (Pulse Penetrant). Spraying occurred on 16 December 2012, and the daily maximum and minimum temperatures in the 2 weeks following application averaged $26.8^{\circ} \mathrm{C}$ and $15.6^{\circ} \mathrm{C}$ respectively.

Five weeks after treatment, the foliage of all plants was removed from pots at ground level, dried and weighed. The effect of each herbicide treatment was calculated as a percentage of the dry weight of untreated plants for that population. Dose response curves for the populations were then determined by fitting the data to a three parameters logistic model:

$$
Y=d / 1+\exp (b(\log (x)-\log (e)))
$$

where $Y$ was plant biomass as a percentage of untreated control, $d$ was the upper limit, $x$ was the herbicide rate, $e$ was the rate of herbicide causing 50\% reduction in biomass $\left(\mathrm{GR}_{50}\right)$ and $b$ was the slope around $e$. Biomass data were fitted to this model using the statistical software $\mathrm{R}$ (Version 2.15.2) with its dose-response curve (DRC) package (Knezevic et al. 2007). The ratio of $\mathrm{GR}_{50}$ values for resistant and susceptible populations were calculated. 


\section{Second experiment}

To confirm the results, the experiment was repeated, using the same techniques as described for the first experiment. Plants used for this experiment were taken from untreated plants that had been growing in pots within a glasshouse from the original material obtained for Experiment 1, and were multiplied up from divided tillers prior to spraying. Treatments for this experiment were applied on 28 February 2013 when plants had an average of 5.0 tillers each. The only difference in treatments for the second experiment was that the highest rate of glyphosate applied to populations was increased to allow improved fitting of dose response curves. Susceptible populations received rates of 0,45 , $90,180,360$ and $720 \mathrm{~g}$ ae/ha; most of the resistant populations received rates of $0,360,720,1440$, 2880 and $5760 \mathrm{~g}$ ae/ha, while one of the perennial ryegrass populations received rates of 0,720 , 1440, 2880, 5760 and $11520 \mathrm{~g}$ ae/ha because in the first experiment it was not adequately controlled by any of the rates applied. The daily maximum and minimum temperatures in the 2 weeks following application averaged $26.1^{\circ} \mathrm{C}$ and $12.2^{\circ} \mathrm{C}$ respectively. Dose response curves were fitted as described for the first experiment.

\section{RESULTS}

The herbicide rates calculated to cause a 50\% reduction in growth $\left(\mathrm{GR}_{50}\right)$ for the Italian ryegrass populations in both experiments are shown in Table 1, and the dose response curves for Experiment 2 are shown in Figure 1. The plants from the Manawatu population (Population SI) were all killed by $360 \mathrm{~g}$ ae/ha of glyphosate, even though growth prior to dying was not reduced as quickly at this rate as for higher rates (Figure 1). The $\mathrm{GR}_{50}$ values for the two populations from Marlborough were significantly higher than for Population SI, and the recommended rate of glyphosate had little effect on these populations. By comparing the $\mathrm{GR}_{50}$ of each Marlborough population against the $\mathrm{GR}_{50}$ of the Manawatu population for the first experiment, it was estimated that Population A was 13.4 times more resistant to glyphosate than Population SI, whereas Population P appeared to be 10.7 times more resistant. Results were very similar for Experiment 2 (Table 1).

The perennial ryegrass population from Manawatu (Population SP) had a very similar $\mathrm{GR}_{50}$ (Table 1) to the Italian ryegrass from Manawatu in Experiment 1, and once again all plants were killed by $360 \mathrm{~g}$ ae/ha of glyphosate. However, as with the Italian ryegrass, the three populations from vineyards had much higher $\mathrm{GR}_{50}$ values. Population $\mathrm{N}$ from Nelson was estimated to be 14.5 times more resistant than Population SP, while one of the Marlborough populations (Population J) appeared to be 10.2 times more resistant (Table 1). The application rates used in the first experiment were not sufficiently high to allow a $\mathrm{GR}_{50}$ value

Table 1 The $\mathrm{GR}_{50}$ (g ae/ha) and R/S ratio of three Italian ryegrass and four perennial ryegrass populations at 5 weeks after application of glyphosate in two experiments.

\begin{tabular}{|c|c|c|c|c|}
\hline \multirow[b]{2}{*}{ Population } & \multicolumn{2}{|c|}{$\mathrm{GR}_{50} \pm \mathrm{SE}$} & \multicolumn{2}{|c|}{$\mathrm{R} / \mathrm{S} \mathrm{GR}_{50}$ ratio } \\
\hline & Experiment 1 & Experiment 2 & Experiment 1 & Experiment 2 \\
\hline \multicolumn{5}{|l|}{ Italian ryegrass } \\
\hline Manawatu SI & $134 \pm 6$ & $126 \pm 5$ & - & - \\
\hline Marlborough A & $1796 \pm 82$ & $1655 \pm 54$ & 13.4 & 13.2 \\
\hline Marlborough P & $1433 \pm 59$ & $1233 \pm 41$ & 10.7 & 9.8 \\
\hline \multicolumn{5}{|l|}{ Perennial ryegrass } \\
\hline Manawatu SP & $127 \pm 9$ & $161 \pm 5$ & - & - \\
\hline Marlborough J & $1304 \pm 121$ & $1533 \pm 53$ & 10.2 & 9.5 \\
\hline Nelson N & $1841 \pm 150$ & $2062 \pm 73$ & 14.5 & 12.8 \\
\hline Marlborough $\mathrm{O}$ & $>2000$ & $4971 \pm 166$ & $>15.0$ & 30.8 \\
\hline
\end{tabular}




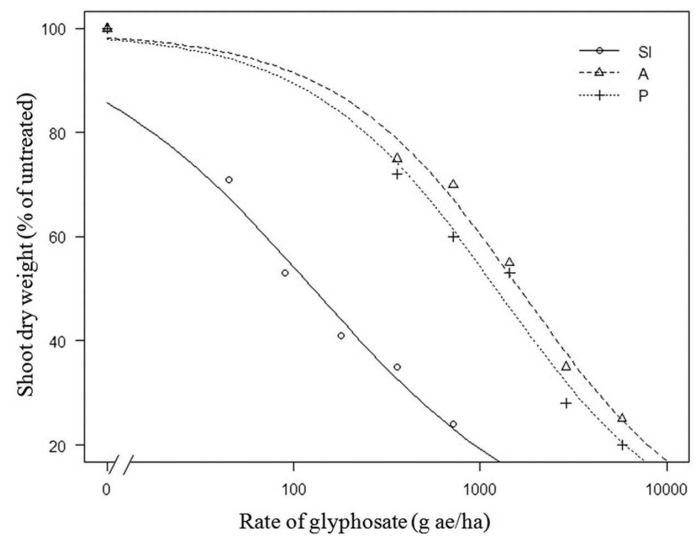

Figure 1 Fitted dose response curves (on logarithmic dose scale) for three populations of Italian ryegrass (SI from Manawatu pasture, A and $\mathrm{P}$ from Marlborough vineyards) for glyphosate using shoot dry weight in Experiment 2.

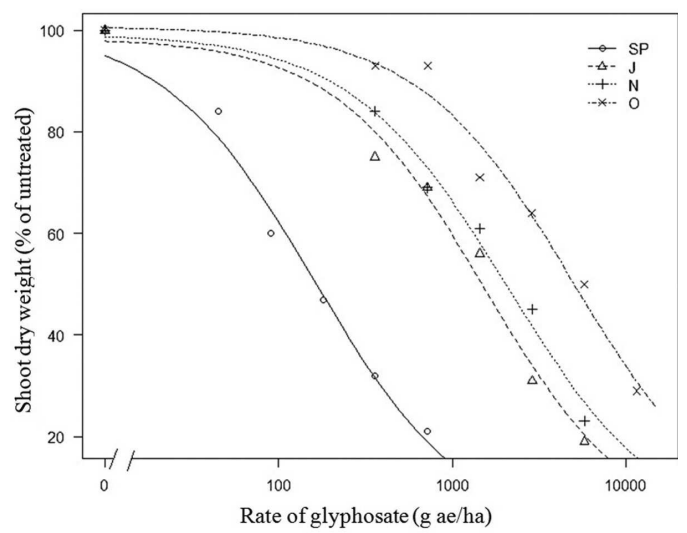

Figure 2 Fitted dose response curves (on logarithmic dose scale) for four populations of perennial ryegrass (SP from Manawatu pasture, $\mathrm{N}$ from Nelson vineyard, $\mathrm{J}$ and $\mathrm{O}$ from Marlborough vineyards) for glyphosate using shoot dry weight in Experiment 2.

to be estimated for Population $\mathrm{O}$, but as the population was less affected than Population N, the level of resistance was assumed to be greater than 15 times.

In the second experiment, the $\mathrm{GR}_{50}$ for each of the perennial ryegrass populations was slightly higher than the first, although the ratios of resistant to susceptible $\mathrm{GR}_{50}$ values remained similar since they were all higher (Table 1). The Nelson population still appeared to be slightly more resistant than Population J. The higher rates used in this trial allowed a $\mathrm{GR}_{50}$ to be calculated for Population O, which was 30 times more resistant to glyphosate than Population SP. Curves for all populations were also able to be fitted (Figures $1 \& 2$ ).

\section{DISCUSSION}

These results confirm that glyphosate resistance has developed within New Zealand vineyards, for both perennial ryegrass and Italian ryegrass. These are the first known cases of glyphosate resistance developing within New Zealand. However, resistance in both of these species has been recorded overseas. Italian ryegrass has developed resistance to glyphosate in several countries (Perez \& Kogan 2003; Jasieniuk et al. 2008) where glyphosate has been used continuously for several years to control weeds in orchards, vineyards and crops. The first case of glyphosate-resistant perennial ryegrass in the world was reported from Argentina with an $\mathrm{R} / \mathrm{S}$ ratio of 10.8 , similar in magnitude to that found with most of the populations studied in this work (Yanniccari et al. 2012). Many of the cases of resistance to glyphosate that have been reported worldwide have been for another member of the Lolium genus, i.e. Lolium rigidum (Heap 2013).

Although four of the populations studied had approximately a 10-fold level of resistance, Population $\mathrm{O}$ had a significantly higher level of resistance, calculated as being 30-fold, suggesting that the mechanism of resistance in this population may differ from the other four. As both target site and non-target site mechanisms of glyphosate resistance have been reported in weed species (Preston et al. 2009), the mechanism of resistance with these biotypes and also the inheritance of the trait is currently being investigated.

As glyphosate is one of the main herbicides used for weed control in New Zealand, these first occurrences of resistance suggest 
current practices may need to change if further resistance is to be avoided. A survey of herbicide practices in Marlborough vineyards in 1997 showed that almost all growers were using glyphosate at that time, though other herbicides were also used during the season, such as amitrole, glufosinate, paraquat and simazine (Dastghieb \& Frampton 2000). Since then, paraquat is no longer permitted to be used in vineyards within the sustainable winegrowing programme, residual herbicides are discouraged and amitrole can only be used in winter, so glyphosate is being increasingly relied on for weed control (Harrington 2012). Improved weed management systems need to be developed both in vineyards and elsewhere in New Zealand to reduce the chance of more glyphosate resistance from developing.

\section{ACKNOWLEDGEMENTS}

The authors wish to thank the people who sent us plant material for this study, and the staff of the Plant Growth Unit of Massey University for assistance with growing the ryegrass. They are also grateful for the financial assistance provided by the Massey University Doctoral Scholarship, the Seed Tech Services Scholarship, the Dan Watkins Scholarship in Weed Science, the Ministry of Primary Industries through the Sustainable Farming Fund and the Foundation for Arable Research.

\section{REFERENCES}

Beckie HJ, Heap IM, Smeda RJ, Hall LM 2000. Screening for herbicide resistance of weeds. Weed Technology 14: 428-445.

Bradshaw LD, Padgette SR, Kimball SL, Wells BH 1997. Perspectives on glyphosate resistance. Weed Technology 11: 189-198.

Dastgheib F, Frampton C 2000. Weed management practices in apple orchards and vineyards in the South Island of New Zealand. New Zealand Journal of Crop and Horticultural Science 28: 53-58.

Franz JE, Mao MK, Sikorski JA 1997. Glyphosate: a unique global herbicide. American Chemical Society, Washington DC, USA. 653 p.
Harrington KC 2012. Avoiding herbicide resistance problems. Romeo Bragato Winegrowers Conference, Blenheim, 24 August 2012. http://weeds.massey.ac.nz/ resist.asp (accessed 23 April 2013).

Heap I 2013. International survey of herbicide resistant weeds. http://www.weedscience. com (accessed 7 April 2013).

Jasieniuk M, Ahmad R, Sherwood AM, Firestone JL, Perez-Jones A, Lanini WT, Mallory-Smith C, Stednick Z 2008. Glyphosate-resistant Italian ryegrass (Lolium multiflorum) in California: distribution, response to glyphosate, and molecular evidence for an altered target enzyme. Weed Science 56: 496-502.

Knezevic SZ, Streibig JC, Ritz C 2007. Utilising $\mathrm{R}$ software package for dose response studies: the concept and data analysis. Weed Technology 21: 840-848.

Nandula VK 2010. Glyphosate resistance in crops and weeds: history, development, and management. John Wiley \& Sons, Inc, Hoboken, NJ, USA. 321 p.

Perez A, Kogan M 2003. Glyphosate-resistant Lolium multiflorum in Chilean orchards. Weed Research 43: 12-19.

Powles SB, Lorraine-Colwill DF, Dellow JJ, Preston C 1998. Evolved resistance to glyphosate in rigid ryegrass (Lolium rigidum) in Australia. Weed Science 46: 604-607.

Preston C, Wakelin AM, Dolman FC, Bostamam Y, Boutsalis P 2009. A decade of glyphosateresistant Lolium around the world: mechanisms, genes, fitness, and agronomic management. Weed Science 57: 435-441.

Simarmata M, Bughrara S, Penner D 2005. Inheritance of glyphosate resistance in rigid ryegrass (Lolium rigidum) from California. Weed Science 53: 615-619.

Wakelin AM, Preston C 2006. A target-site mutation is present in a glyphosate-resistant Lolium rigidum population. Weed Research 46: 432-440.

Yanniccari M, Istilart C, Gimenez DO, Castro AM 2012. Glyphosate resistance in perennial ryegrass (Lolium perenne L.) from Argentina. Crop Protection 32: 12-16. 